\title{
THE ESSENCE OF FORMATION OF COMMUNICATIVE CULTURE OF STUDENTS IN THE PROCESS OF EXTRACURRICULAR WORK IN HIGHER TECHNICAL EDUCATIONAL INSTITUTIONS
}

\begin{abstract}
The essence of the concept of "communicative culture" and its importance in the training of engineers at technical higher educational institutions are revealed in the article. The content of extracurricular work in the training of engineers in modern technical higher educational institution is detected. The components of extracurricular work and their characteristics are clarified and specified. The conditions of the educational environment that influence the development of students and the results of their interaction are described in the article. The factors that affect the efficiency of extracurricular work at higher technical educational institutions are identified. Traditional and interactive methods that are effective in the formation of communicative culture of future engineers are pointed out. The principles of implementation of the program are defined and characterized: maintenance of activity of the student by council and own example of the teacher; definitions in activity of students of the most successful moments: success advancing, updating of achievements; removal at students of fear before activity and their psychological support; support on reception of personal need as an important factor of motivation activity of students; openness and pluralism of opinions and judgments in the solution of various problems, the analysis of events and the phenomena; tolerance to the opponent; argumentativeness of own reasons, etc. And also four stages of its introduction are characterized. Implementation of the program provides formation of students at higher technical educational institutions: systems of communicative knowledge; systems of the valuable relations to this knowledge and respectively their transformation into personal installations, requirements, motives; systems of communicative skills practical communicative behaviour and activity.
\end{abstract}

Key words: communicative culture, formation of communicative culture, higher technical educational institution, extracurricular work.

Today, more than ever, high school faces the challenge to rethink its role in training the specialists of new generation. One of the solutions to this problem is the creative education that provides the creative work of students through their direct participation in active research in order to generate new knowledge. Taking into account the responsibility of higher school for education of a future creative specialist who can be highly qualified, competitive, and active in social and professional life increases. This fact requires the creation of such an educational system that will seamlessly combine high-quality training of future engineers in the chosen sphere with their deep psychological, educational and communicative training. It should provide students with the opportunity to organize the professional interaction with different groups of people for effective joint activities in achieving productive and socially significant goals.

It is evident that the communicative culture of engineers is a social phenomenon in its broad sense. The status of objects and subjects of communicative process is defined as a process of ideas' exchange in the communication process. Therefore, the requirements for the communicative culture of students of higher technical school appear as an important prerequisite for their professional competence. Formed communicative culture of a future engineer continues to make real professional growth and self-realisation of a specialist, whose professional activity requires cooperation in the field of "human-technology". Future engineers must be prepared to a broad range of business contacts, which are based on the principles of mutual respect, support, fairness and objectivity.

Thus, the important task of higher education is the argumentation of the development of communicative culture of future engineers to ensure the success in performing their professional duties and resolution of a variety of routine tasks in time.

Analysis of psychological and educational literature affords ground for the statement that communicative culture is an essential characteristic of a specialist, an indicator of the training level and an integral part of professional and pedagogical culture and culture of an individual in particular, as well as the degree of acquisition of communicative experience in terms of knowledge, skills; effective level of formation of communicativeness as a relatively steady personal characteristic that promotes successful creative understanding, learning, use and transfer of information. For example, I. Tymchenko defines communicative culture of a future specialist as a system of beliefs and actions that target for an individual as the model to meet the needs of the selfrealization and the way to achieve goals while interacting with others [9, p. 15]. In turn, O. Havrylyuk regards communicative culture as a complex dynamic individual formation, reflecting the level of a person social development, his willingness to communicative activity, a system of beliefs and actions that ensure meeting the needs of self-realization and a way to achieve the goals while communicating, fruitful benevolent cooperation of people in different spheres of life [4, p. 44]. A. Bilonozhko defines communicative culture as a set of specific communicative personal characteristics, abilities, knowledge, skills due to which an individual prevents the appearance of psychological difficulties and predicts the impact of interpersonal and professional interaction. The author notes that communicative culture of an individual is a manifestation of personal reflection, internalised 
experience of a human culture, which influences the individual characteristics of a person. Communicative culture is an incentive to self-realization that mediates the attitude to life that is a conscious search of oneself, the desire and the need for self-improvement, valuable relation to life and society [3, p. 14].

The aim of the article is to analyze the development of communicative culture of students of higher technical educational institutions in the process of extracurricular work.

The analysis of pedagogical, psychological and philosophical scientific literature suggests that the problems of professional training in higher educational institutions (S. Dotsenko, O. Karpenko, D. Paschenko), the use of information technologies in the educational process of higher educational institutions (R. Hurevych, M. Kozyar, V. Monakhov, V. Strelnikov, N. Tverezovska), monitoring of educational work at higher pedagogical educational institutions (A. Denysenko) are considered by scientists from different aspects.

The analysis of scientific sources indicates that the means that provide the operation and development of the process that requires a certain arrangement or organization are considered to be very important. The organization is comprehended as a process of achieving certainty in internal and external relations of systems required for providing steadiness of systems in a changing environment [7, p. 12].

The analysis of psychological and educational literature helped us to find out that training as an integrative teaching and educational activity involves the interaction of two parties - subject and object that are in some educational space of a higher technical educational institution. In other words, certain means of implementation of a set of processes should be allocated in the process of organizing of a particular activity for its effectiveness [8, p. 91].

On the basis of the analysis of psychological and educational literature the formation of communicative culture of students in higher technical educational institution is defined as a controlled process that involves reorientation of extracurricular educational work from subjective on personally-oriented, that gives an opportunity to consider the educational information as a means of professional development of a future engineer and promotes the formation of a creative style of any activity, steady demand for dynamic actions, improvisation and individual solving of communication tasks for acquiring and enriching the communication experience. This, in turn, requires a proper educational environment in which students would feel comfortable, that is to socialize actively and creatively in it [5, p. 37].

K. Tillman regards such prerequisites of educational environment that influence the students' development as: provide individualization of a student at the level of social needs; provide life-sustaining activity of a student in accordance with household needs; help students navigate in social, pedagogical, psychological issues, learn the elder generations experience, understand their own vocation, determine the place in society, meet their needs and interests, use them for the benefit of other people [10, p. 10].

The result of such prerequisites interaction should be considered as a positive dynamic - change of the levels of students' communicative culture formation. Thereat, the set of these prerequisites should ensure the development of communicative culture and its internal dynamics will change in the process of training, which will allow students to move from one level of its formation to another.

As it has been noted, the extracurricular work is an important factor in student's communicative culture formation if there are the prerequisites for the maximum development of each student's potential opportunities and creative atmosphere at higher technical educational institution.

The system of extracurricular work for the formation of communicative culture of a future engineer includes such components as: extracurricular teaching and research work of students, extracurricular educational work of creative nature and training of students during externship.

As a part of the study it was found that teaching and research, scientific and research activities of future engineers are an important means to improve the quality of professionals' training and education able to develop and implement the newest technologies in practice. An important prerequisite of improving the efficiency of scientific and research activity is its relevant organization that provides a rational correlation between different by content students' scientific works (theoretical, search and methodological researches) and different organizational forms of activity (laboratory, individual lessons, conferences). The need to consider methods of progressive involvement of students in research work from simple to complex, from abstract preparation to the self-study is emphasized. The key point is to improve the professional orientation of the students' research work which is one of the most effective ways to develop the students' ability to self-creative activity that actually becomes a necessary and indispensable element of training.

Thus, learning, research and scientific work of students at higher technical educational institutions is a form of the extracurricular work, contributing to the training of future engineers to innovative, individual work, free and internally motivated, and ensuring a successful adaptation of a graduate to a real innovative technical process.

Experimental studies show that the effectiveness of the extracurricular work at higher technical educational institutions depends on the implementation of: competence of a lecturer in the application of psychological and educational theory and practice (approaches, methods, techniques); continuity of educational activities according to age, social and psychological characteristics of students and professional specificity; opinion that reflects the interests of the society and the state.

Achievement of the objective, performance of the tasks and implementation of the content of students' communicative culture should be implemented by means of a set of methods, tools and forms, which are 
the components of a variety of personally-oriented technologies of teacher's activities. Thus, the introduction of traditional and interactive methods in the extracurricular work appeared effective in communicative culture formation of future specialists in the engineering sphere.

In the study, it was found that the formation of communicative culture will be more successful if: provide purposefulness and systematic character of realizing extracurricular work focused on the interaction, collaboration and co-creation; consider a systematic approach and strategies of the teaching communicative interaction in the organization of extracurricular work in students' groups; implement forms and methods of extracurricular work that contribute to the individualization of the educational process; introduce basic elements, criteria and indicators of communicative culture to students; base on the communicative potential and communication skills of each student in the process of extracurricular work; conduct diagnosis of the level of students' communicative culture formation.

Conclusions. To be highly professional and creative in modern society a specialist should not only possess the knowledge and skills of a specific specialty. It is also necessary to form professionally important qualities which would allow achieve high professional skills in the future. In this context, the extracurricular work in higher technical educational institution is considered as one of the most important factors of communicative culture formation of future engineers that will be formed in such a way as to create prerequisites for the maximum development of each student's abilities and capabilities. In the process of extracurricular work it is important to remember the prerequisites of its effectiveness: the formation of an individual morality is based on the student's human activities and communication with others; correlation of external influences with the individual characteristics of students; knowledge of the sources and motivation of student's self-determination.

\section{Bibliography:}

1. Білоножко А. В. Соціально-психологічні чинники становлення комунікативної культури майбутнього юриста в процесі професійної підготовки : автореф. дис. ... канд.. псих. наук : 19.00 .05 «Соціальна психологія, психологія соціальної роботи» ; Інститут психології ім. Г. С. Костюка АПН України. Київ, 2008. 21 с.

2. Галацин К. О. Моделювання процесу формування комунікативної культури майбутніх інженерів. Вісник Харківської державної академії культури. Харків, 2013. Вип. 41. С. 257-261.

3. Leshchenko M. Lavrysh Yu. Halatsyn K. (2018). The role of content and language integrated learning at Ukrainian and Polish educational systems: challenges and implication. Advanced Education, 9, 17-25. DOI: 10.20535/2410-8286.133409

4. Гаврилюк О. О. Формування комунікативної культури студентів вищих педагогічних закладів засобами поза аудиторної роботи. Творча особистість учителя: проблеми теорії і практики. Київ, 2001. Вип. 5. С. 115-160.

5. Садова В. В. Формування комунікативної культури вчителів початкових класів у процесі методичної роботи : автореф. дис. ... канд. пед. наук : 13.00.04. Харків, 2000.18 с.

6. Тимченко I. I. Формування комунікативної культури студентів у процесі вивчення предметів гуманітарного циклу : автореф. дис. ... канд. пед. наук : 13.00 .04 «Теорія і методика професійної освіти» ; Харківський держ. педагогічний ун-т ім. Г. С. Сковороди. Харків, 2001. 20 с.

7. Уваркіна О. В. Формування комунікативної культури студентів вищих медичних закладів освіти в процесі вивчення психолого-педагогічних дисциплін : автореф. дис. ... канд. пед. наук : 13.00.04. Київ, 2003. 22 с.

8. Klaus-Jurgen Tillman. Teorie socjalizacji. Wydawnictwo naukow PWN. Warszawa, 2006. 300 s. S. 9-11.

\section{References:}

1. Bilonozhko, A.V. (2008). Sotsial'no-psykholohichni chynnyky stanovlennya komunikatyvnoyi kul'tury maybutn'oho yurysta $\mathrm{v}$ protsesi profesiynoyi pidhotovky [Social and psychological factors of formation of the communicative culture of the future lawyer in the process of professional training]. Extended abstract of candidate's thesis. Kyiv [in Ukrainian].

2. Halatsyn, K. O. (2013). Modelyuvannya protsesu formuvannya komunikatyvnoyi kul'tury maybutnikh inzheneriv (Modelling the process of formation of the communicative culture of future engineers). Visnyk Kharkivs'koyi derzhavnoyi akademiyi kul'tury Bulletin of Kharkiv state Academy of culture, 41, 257-261. [in Ukrainian].

3. Leshchenko, M., \& Lavrysh, Yu., Halatsyn, K. (2018). Rol' zmistu ta movnoho intehrovanoho navchannya v ukrayins'kykh ta pol's'kykh osvitnikh systemakh: vyklyky ta naslidky (The role of content and language integrated learning at Ukrainian and Polish educational systems: challenges and implication). Vyshcha osvita - Advanced Education, 9, 17-25. DOI: 10.20535/2410-8286.133409 [in English].

4. Havrylyuk, O. O. (2001). Formuvannya komunikatyvnoyi kul'tury studentiv vyshchykh pedahohichnykh zakladiv zasobamy poza audytornoyi roboty (Formation of the communicative culture of students in higher educational institutions by means of extracurricular work). Tvorcha osobystist' uchytelya: problemy teoriyi i praktyky - Creative personality of the teacher: problems of theory and practice, 5, 115-160. [in Ukrainian].

5. Sadova, V.V. (2000). Formuvannya komunikatyvnoyi kul'tury vchyteliv pochatkovykh klasiv u protsesi metodychnoyi roboty [Formation of the communicative culture of primary school teachers in the process of methodical work]. Extended abstract of candidate's thesis. Kharkiv [in Ukrainian].

6. Tymchenko, I.I. (2001). Formuvannya komunikatyvnoyi kul'tury studentiv u protsesi vyvchennya predmetiv humanitarnoho tsyklu [Formation of the communicative culture of students in the process of studying subjects of humanitarian cycle]. Extended abstract of candidate's thesis. - Kharkiv [in Ukrainian].

7. Uvarkina, O.V. (2003). Formuvannya komunikatyvnoyi kul'tury studentiv vyshchykh medychnykh zakladiv osvity v protsesi vyvchennya psykholoho-pedahohichnykh dystsyplin [Formation of the communicative culture of students in higher medical educational institutions in the process of studying psychological and pedagogical disciplines]. Extended abstract of candidate's thesis. Kyiv [in Ukrainian].

8. Tillman, Klaus-Jurgen. (2006). Teorie socjalizacji (Theory of Socialisation). Warszawa: Wydawnictwo naukow PWN [in Poland]. 
Галацин К. О. Сутність формування комунікативної культури студентів у процесі позааудиторної роботи у вищих технічних навчальних закладах

Розкривається сутність поняття “комунікативна культура» та їі важливість у процесі підготовки інженерів у технічному 3ВО; виявлено і обумовлено зміст позааудиторної роботи в процесі підготовки інженерів у сучасному технічному 3ВО; уточнено і конкретизовано компоненти позааудиторної роботи та їхні особливості; визначено умови освітньо-виховного середовища, які впливають на розвиток студентської молоді, та описано результати їх взаємодї; виділено чинники, які впливають на ефективність реалізації позааудиторної роботи у закладах вищої технічної освіти, вказані традиційні та інтерактивні методи, які є ефективними у формуванні комунікативної культури майбутніх фахівиів інженерної сфери. Мету досягнено через реалізацію завдань: розкриття сутності комунікативної культури студентів ЗВТО в позааудиторній роботі; визначення змісту, форм і методів формування комунікативної культури в майбутніх інженерів у процесі позааудиторної роботи. Наголошується на тому, щчо позааудиторна робота студента є продовженням аудиторної роботи, в якій домінує елемент самореалізаиї; вона дає змогу студентам гармонізувати внутрішні та зовнішні фактори формування професійної та комунікативної культури, створює додаткові умови для реалізації внутрішнього потенціалу, задоволення тих потреб, які в процесі аудиторної роботи не задовольняються. Позааудиторна робота має бути орієнтована на особистість студента. Як висновок, зауважується, щз власне зростання ролі позааудиторної та самостійної роботи є однією із провідних ланок перебудови навчальновиховного процесу у вищій школі. Реформування вищої школи в Украӥні й покликане насамперед на вдосконалення професійної освіти, зміст якої полягає не лише у формуванні професійної компетентності спеціалістів, але й у розвитку їхніх позитивних особистісних якостей в цілому й комунікативності та комунікативної культури зокрема. Важливу роль у формуванні комунікативної культури студентів закладів вищої технічної освіти відіграють ігрові технології, які забезпечують не лише оволодіння майбутніми фахівиями трунтовними професійними знаннями, але й готовність їх до професійної та міжособистісної взаємодї.

Ключові слова: комунікативна культура, формування комунікативної культури, вища освіта, заклад вищої технічної освіти, позааудиторна робота.

\section{УДК 377.5}

DOI https://doi.org/10.31392/NPU-nc.series5.2019.71.15

Гаргаун Н. М.

\section{ФОРМУВАННЯ ЕКОНОМІЧНОЇ КУЛЬТУРИ МОЛОДШИХ СПЕЦІАЛІСТІВ ТЕХНІКІВ-ЕЛЕКТРИКІВ У ПРОЦЕСІ ФАХОВОЇ ПІДГОТОВКИ В КОЛЕДЖІ}

Стаття присвячена темі формування економічної культури молодших спеціалістів техніків-електриків у проиесі фахової підготовки в коледжі. Слід зауважити, щуо окремо взяті навчальні дисципліни не в змозі самостійно забезпечити формування в майбутніх фахівців економічної культури. Процес формування економічної культури майбутніх молодших спеціалістів електротехнічного профілю у процесі фахової підготовки більшою мірою змістовно прив'язаний до вивчення певних навчальних дисииплін.

Відповідно до гуманістичної парадигми освіти професійна підготовка має бути орієнтованою не на об'єкт, а на створення умов для розвитку особистості як суб'єкта власної діяльності. Особистісно-орієнтований підхід передбачає ией процес як такий, ще відбувається відповідно до потреб особистості студента з ї орієнтацією на самоактуалізацію згідно із власними інтересами та здібностями. Особистість має бути соціально активною, творчою, гармонійною, відповідальною за свої рішення та відкритою до інноваиій. Тому для вирішення завдань нашого дослідження була розроблена особистісно орієнтована модель організаиійно-методичної системи формування у молодших спеціалістів техніків-електриків економічної культури в процесі фахової підготовки, яка являє собою відкриту, складну динамічну єдність взаємопов'язаних і взаємодіючих компонентів (мета, завдання, методологічна основа, педагогічні умови, зміст, технології, освітнє середовище, критерії та рівні сформованості, результат).

Ми поставили своїм завданням створити педагогічну модель як динамічне комплексне утворення в контексті фахової підготовки в иілому. Проблема формування економічної культури молодших спеціалістів електротехнічного профілю у процесі фахової підготовки розглядається нами на методологічному, теоретичному та організаційно-методичному рівнях з позииій сучасної педагогічної науки з розкриттям ї̈ теоретичного та практичного значення. Дослідження є багатоаспектним, складним та міждисичплінарним. Маючи складну природу, цеей процес поєднує в собі педагогічні, психологічні, соціальні, економічні та культурологічні складники і може бути представлений у вигляді комплексної педагогічної моделі.

Ключові слова: економічна культура, формування, педагогічні умови, молодші спеціалісти техніків-електриків, інноваційні педагогічні технології, навчання, модель, фахова підготовка.

Модель формування економічної культури молодших спеціалістів техніків-електриків побудована з урахуванням основних положень теорії моделювання. У науковій інтерпретації з поняттям «модель» зв'язані два близьких один одному, але різних поняття. По-перше, під моделлю в широкому сенсі розуміють теоретично або практично створену структуру, яка відтворює ту чи іншу частину дійсності у спрощеній (схематизованій або ідеалізованій) і наочній формі; по-друге, модель, що проектується, розуміють за допомогою іншої, більш вивченої (макро- або мікро-) системи за аналогією відношення схожості систем, які складаються з різних елементів, але мають однакову структуру. 